\title{
Effect of gamma irradiation on physicochemical characteristics and microbiological quality at different ratio of tapioca and potato starches of flat rice noodle
}

\author{
${ }^{3}$ Ahmad Zainuri, M.D., ${ }^{1, * W a n-Z u n a i r a h, ~ W . I ., ~}{ }^{1}$ Farah-Nadiah, A.R. ${ }^{1}$ Fatimah, M.H.B., \\ ${ }^{1}$ Nor-Khaizura, M.A.R., ${ }^{2}$ Nor Afizah, M., ${ }^{2}$ Ismail-Fitry, M.R., ${ }^{2}$ Radhiah, S. and \\ ${ }^{2}$ Nur Hanani, Z.A. \\ ${ }^{1}$ Department of Food Science, Faculty of Food Science and Technology, Universiti Putra Malaysia, 43400, \\ UPM Serdang, Selangor, Malaysia \\ ${ }^{2}$ Department of Food Technology, Faculty of Food Science and Technology, Universiti Putra Malaysia, \\ 43400, UPM Serdang, Selangor, Malaysia \\ ${ }^{3}$ Malaysian Nuclear Agency, 43800 Dengkil, Selangor, Malaysia
}

\section{Article history: \\ Received: 10 February 2020 Received in revised form: 26 March 2020 \\ Accepted: 1 April 2020 Available Online: 5 May 2020}

\section{Keywords:}

Flat rice noodle,

Tapioca starch,

Potato starch,

Gamma irradiation,

Physicochemical

characteristics,

Microbiological quality

\section{DOI:}

https://doi.org/10.26656/fr.2017.4(5).063

\begin{abstract}
Flat rice noodle is classified under non-wheat noodles due to the absence of gluten and required gelatinization of starch during processing. It is also very susceptible to spoilage and has a short shelf-life because of the high moisture content. This study was conducted to investigate and compare the effect of gamma irradiation on the physicochemical characteristics and microbiological quality of containing two different starches. Tapioca starch (TS) and potato starch (PS) were incorporated into the formulations at 3 levels (3\%, $8 \%$ and $11 \%$ ) and was irradiated at 4 doses of 0 (control), 4, 6, and $8 \mathrm{kGy}$ with dose rate of $42.78 \mathrm{~Gy} / \mathrm{min}$ by using ${ }^{60}$ Cobalt. Total plate count (TPC) was performed where samples were stored at $8^{\circ} \mathrm{C}$ and examined for day $1,3,5$, and 7 . Results showed that all doses of irradiation did not significantly $(\mathrm{p}>0.05)$ affected the moisture content and water activity of samples. However, gamma irradiation significantly $(\mathrm{p}<0.05)$ decreased the $\mathrm{pH}$ value, cooking yield, lightness, and hardness of the samples; whereas it significantly $(\mathrm{p}<0.05)$ increased the cooking loss, colour ( $\mathrm{a}^{*}$ and $\mathrm{b}^{*}$ ), and breaking length. Meanwhile, cooking yield, lightness, and hardness of samples containing PS were higher compared to samples containing TS. Moisture content for samples containing both TS and PS was higher compared to samples containing single starch. TPC showed that irradiation was able to control microbial growth. Moreover, no microbial load was detected on samples irradiated at $8 \mathrm{kGy}$ until day 7. It was thus shown that increased doses in gamma irradiation could improve microbiological quality of flat rice noodles.
\end{abstract}

\section{Introduction}

Rice is a staple food in most Asian countries where it is commonly consumed as cooked milled rice on a daily basis. Apart from that, a small portion of rice is ground into flour to produce other food products. Rice noodle, a rice flour-based product, is one of the most famous varieties of Asian noodles and has been widely consumed throughout Southeast Asia (Hormdok and Noomhorm, 2007). According to Fu (2008), rice noodles are traditionally made from long-grain rice with medium to high amylose content ( $>22 \%$ amylose) where rice high in amylose content provides bright colour to noodles. Fresh rice noodles can be divided into two types depending on the processing methods; extruded rice noodles (Zhafen) and flat rice noodles (Qiefen). Zhafen is processed to have a round-shaped with a range of diameter from 1-3 mm while Qiefen is processed to have thin strips shape with a range of thickness from 1-2 mm (Lu and Collado, 2010).

Generally, flat rice noodles or known locally as kuey teow are products from a mixture of rice flour and water. As the main ingredient used to produce flat rice noodles, rice flour has low protein and its protein has no ability like wheat gluten to help create cohesive dough structure (Malahayati et al., 2015; Lu and Collado, 2019). Due to this absence of gluten in rice flour, flat rice noodle requires gelatinization of starch such as potato or tapioca starches during processing. These starches can act as a 
binder for the batter and also can provide a structural network to the noodles (Lu and Collado, 2010; Sandhu et al., 2010). In addition, potato and tapioca starches have been widely used as ingredients to enhance the texture of rice noodle products.

Furthermore, flat rice noodle is one of perishable food products because it has a high moisture content (Sangpring et al., 2015). To eliminate food spoilage microorganisms, they further stated that flat rice noodle can be transformed into dried rice noodles where the moisture content dropped to $10-12 \%$; but causes hard texture after cooking. Researches show that nowadays, most people prefer fresh rice noodles rather than dried ones because of its unique flavour, taste and texture (Jianming, 1998; Li et al., 2011). Good quality of fresh flat rice noodle has characteristics of soft texture, smooth mouth feels and has the appearance of white colour. However, fresh flat rice noodle has short shelf-life and can spoil easily within one day if not refrigerated. Even so, it may not last longer upon storage because of its physicochemical characteristics that promote the growth of microorganisms (Ismail et al., 2016).

In order to increase the shelf-life of fresh flat rice noodle, artificial or chemical food preservatives such as sodium benzoate and benzoic acid have been widely used (Li et al., 2011; Klinmalai et al., 2017). It must be highlighted that consumers are very concerned about the safety of the foods they consume. This situation has increased the demand for fresh noodles free from chemical food preservatives (Klinmalai et al., 2017). Thus, non-artificial food preservatives or known as natural food preservatives like chitosan is preferred. Unfortunately, the usage of natural preservatives in extending the shelf-life of fresh noodles could only make it last for a few days more (Li et al., 2011).

Instead of using preservatives, methods of food preservation can be applied to prolong the shelf-life of fresh flat rice noodle. According to Odueke et al. (2018), irradiation technology, a non-thermal treatment being used in food processing can act as an alternative to thermal processing due to its capability to preserve food quality attributes. Gamma irradiation has been proven to be an efficient method in reducing bacterial contamination, improving food safety, extending shelflife of perishable foods and retaining its organoleptic properties as well as nutritional attributes (Sung, 2005; Li et al., 2011; Maherani et al., 2016). It is worth emphasising that irradiated foods are not radioactive because the absorbed energy not being powerful enough to affect the neutrons in the nuclei of the food molecules (Food Irradiation and Processing Alliance (FIPA), 2006).

There have been studies on the use of gamma irradiation in increasing shelf-life of foods including fresh noodles while preserving their nutritional and sensorial quality. Fresh noodle product using wheat, after being exposed to irradiation at 8-10 kGy killed most of the bacteria and the acidity was kept around 6.0. Jianming (1998) also observed the noodles looks fresh and smells good as fresh within 10 days. However, less study has directly examined the effects of gamma irradiation on fresh flat rice noodle and the combination on the shelf-life, physicochemical properties. The purpose of this research was to investigate and compare the effect of gamma irradiation on the physicochemical characteristics and microbiological quality of flat rice noodles with the addition of potato starch, tapioca starch and the combination of both starches.

\section{Materials and methods}

\subsection{Materials}

Materials for flat rice noodles include rice flour, tapioca and potato starches, salt and vegetable oil, were purchased from Tesco Stores (Malaysia) Sdn. Bhd. at IOI City Mall, Putrajaya. Unsterile deionised water was used for the preparation variety of flat rice noodles.

\subsection{Preparation of noodles}

The formulations for flat rice noodle as shown in Table 1 were prepared according to the method described by Sangpring et al. (2015) and Thomas et al. (2014) with some modifications. Firstly, rice flour, salt and distilled water were weighed and mixed. Two types of starch were added into the batter according to the percentage stated in each formula. Then, the mixture was whisked using stainless steels wire whisk for 1 min to allow all ingredients to dissolve. Vegetable oil was brushed onto a stainless steel round plate (circumference, 13.70 in). Each $30 \mathrm{~mL}$ of the batter was poured onto the oiled round plate and spread evenly to form a sheet at quarter thickness. After that, a round plate with batter was placed in a steamer closed with a lid and was steamed at $100^{\circ} \mathrm{C}$ for 5-6 min until cooked to complete gelatinization and to obtain a fresh sheet. Once completed, the freshly steamed noodle sheet on the round plate was removed from the steamer and was again coated with vegetable oil. After that, the round plate with the noodle sheet was cooled at room temperature and the sheet was pulled from the round plate. Noodle sheets were sliced into small strips with approximately $1 \mathrm{~cm}$ in width. All noodles with different formulations prepared were packed in sealed, clean polypropylene (PP) bags (6 in $\mathrm{x} 9$ in) and were kept for one day in chiller $\left(8^{\circ} \mathrm{C}\right)$ before given irradiation treatment. Hygiene status of all the equipment was under control condition. 
Table 1. Formulations for flat rice noodles with two different starches; Tapioca starch (TS) and potato starch (PS).

\begin{tabular}{lcccc}
\hline \multirow{2}{*}{ Ingredients (\%) } & \multicolumn{4}{c}{ Formulation } \\
\cline { 2 - 5 } & $11 \%$ TS & $11 \%$ PS & $8 \%$ TS \& 3\% PS & $3 \%$ TS \& 8\% PS \\
\hline Rice flour & 22 & 22 & 22 & 22 \\
Tapioca starch & 11 & - & 8 & 3 \\
Potato starch & - & 11 & 3 & 8 \\
Water & 66 & 66 & 66 & 66 \\
Salt & 0.5 & 0.5 & 0.5 & 0.5 \\
Vegetable oil & 0.5 & 0.5 & 0.5 & 0.5 \\
\hline
\end{tabular}

\subsection{Gamma irradiation treatment}

Gamma irradiation treatment for flat rice noodle was done at Malaysia Nuclear Agency, Dengkil, Selangor. Each formulation was treated at dose levels of 0 (control), 4, 6, and 8 kGy. Packages (250 g) were individually packed in sealed, clean polypropylene (PP) bags and were placed inside four cardboard boxes (17.6 $\mathrm{cm} \times 27.6 \mathrm{~cm} \times 8.5 \mathrm{~cm}$ ) to maximise the dose received. Three out of four cardboard boxes with samples were then irradiated at different intended doses $(4,6$, and 8 $\mathrm{kGy}$ ) by using an irradiator with a ${ }^{60}$ Cobalt source. The dose rate was $42.78 \mathrm{~Gy} / \mathrm{min}$. All samples were stored in the chiller for 7 days with a temperature of $8^{\circ} \mathrm{C}$ after irradiation for further analyses.

\subsection{Determination of physicochemical properties}

Moisture content was determined by the AACC (2000) moisture procedure 44-15A. Water activity $\left(\mathrm{a}_{\mathrm{w}}\right)$ was measured and determined by following Nielsen, (2017) and AOAC method 978.18 (AOAC, 2000). While $\mathrm{pH}$ value determination followed the procedure by Ho and Che Dahri (2016). Triplicates of each sample from the different formulation with different doses were analysed.

\subsubsection{Moisture content}

Moisture content was measured using the oven drying method (AACC, 2000). The empty crucible was heated for $30 \mathrm{~min}$ in a universal oven at $105 \pm 2^{\circ} \mathrm{C}$. Then, the crucible was cooled in a desiccator until it reached room temperature, approximately 20 mins. The dried crucible was weighed and flat rice noodle samples $(5 \pm 0.05 \mathrm{~g})$ were placed inside the dried crucible. The crucible containing samples was again placed in universal oven at $105 \pm 2^{\circ} \mathrm{C}$ for $48 \mathrm{hr}$. After that, crucible containing dried samples was cooled in a desiccator for 20 min and was weighed. MC was determined by using the equation below:

$$
\mathrm{MC}(\%) \text { of wet-weight }=(\mathrm{a}-\mathrm{b}) / \mathrm{a} \times 100
$$

Where $a=$ weight of the sample used, and $b=$ dry weight of the sample

\subsubsection{Water activity}

Water activity $\left(\mathrm{a}_{\mathrm{w}}\right)$ of each flat rice noodle sample was determined by using Aqualab Model Series 3 TE (Pullman, Washington, USA) following the method of AOAC (2000). It is a measurement method of Dewpoint at $24-25^{\circ} \mathrm{C}$. The reading was taken approximately $60-90$ $\mathrm{s}$.

\subsection{3 $\mathrm{pH}$ value}

The pH meter (Jenway 3505, UK) was calibrated first before taking any reading by using buffered solutions; $\mathrm{pH} 4.0$ and 7.0 at $25^{\circ} \mathrm{C}$. Approximately $10 \mathrm{~g}$ of flat rice noodle samples were added into $100 \mathrm{~mL}$ of distilled water and blended for $60 \mathrm{~s}$ using blender (MX$898 \mathrm{M})$ to obtain a uniform mixture. After that, the mixture was filtered using a muslin cloth. The $\mathrm{pH}$ value was then measured.

\subsection{Cooking properties of flat rice noodle}

Cooking yield of flat rice noodle was determined and slightly modified as described by Zawawi et al. (2014). Distilled water $(50 \mathrm{~mL})$ in a beaker was heated on a hotplate until it reached $100^{\circ} \mathrm{C}$. After that, $5 \mathrm{~g}$ of samples were cooked in the beaker for $60 \mathrm{~s}$ while covering the sample with aluminium foil during the cooking process to prevent evaporation. Then, the cooked noodles were immediately removed from cooking water and cooled for 3 mins. The samples were weighed. The cooking yield was measured using the equation stated below:

Cooking yield $(\%)=$ (weight of noodle after cooked/ weight of uncooked noodle) x 100

While cooking loss was determined following the method described by Finagenov and Glagovsky (2005) with slight modifications. The cooking water from the cooking yield method was transferred into a dried crucible and left to dry to a constant weight for approximately $24 \mathrm{hrs}$ in the universal oven at $105 \pm 2^{\circ} \mathrm{C}$. After that, the crucible was cooled in a desiccator for 20 mins and the solid loss during cooking was calculated. The cooking loss was measured using the equation stated below: 
Cooking loss $(\%)=(\mathrm{A}-\mathrm{B}) \times(100 /($ weight of uncooked noodle))

Where $\mathrm{A}=$ weight of crucible + dried residue in the cooking water, and $\mathrm{B}=$ weight of the crucible

\subsection{Determination of colour}

The colour for control and irradiated flat rice noodle samples were measured using a calibrated handheld chromameter (Minolta, R-300). Colour values of L*, $a^{*}$ and $b^{*}$ were based on CIELAB (Klinmalai et al., 2017) where L* (lightness/darkness), a* (redness/greenness) and $b^{*}$ (yellowness/blueness). The samples were packed tightly in a sealed polypropylene (PP) bag. During analysis, a chromameter was placed on the surface of the PP bag. All readings were conducted in the replication of three for each formulation with different doses.

\subsection{Texture properties analysis}

To determine textural properties, the method used was slightly modified from a previously published method (Chin et al., 2012; Zawawi et al., 2014). The Texture Profile Analysis (TPA); hardness of flat rice noodle samples were analysed using an instrument called CT3 Texture Analyzer (TexturePro CT V1.4, USA) fitted with a $4.5 \mathrm{~kg}$ load cell and a probe of knife-edge (clear acrylic $8 \mathrm{~g}, 60 \mathrm{~mm}$ ) was used. Three strands of samples were arranged at one time in a straight manner on the fixture base table that had been set up. The strands were cut using knife-edge probe (twice) at a test speed of $2 \mathrm{~mm} / \mathrm{sec}$. The distance of the probe from the base table was set at $10 \mathrm{~mm}$ and five measurements of each formula with different doses were determined. The same analyser was used for tensile tests; breaking length with dual grip assembly as a probe. A strand of each noodle sample was griped at both ends of dual grip assembly. Trigger load used was $6.8 \mathrm{~g}$ and five measurements of each formula with different doses were collected under this test with 1 $\mathrm{mm} / \mathrm{sec}$ pre-test speed, $1 \mathrm{~mm} / \mathrm{sec}$ tests speed and $1 \mathrm{~mm} /$ sec post-test speed (Sirichokworrakit et al., 2015).

\subsection{Morphological structure analysis}

The analysis followed the method of Ismail et al., (2016). Morphology of starch granules of flat rice noodles was scanned using a Scanning Electron Microscope (SEM). Control and irradiated samples were wiped with tissue to remove the oil and were cut at the dimension required for scanning area (approximately 0.4 $\mathrm{cm} \times 0.2 \mathrm{~cm}$ ) before mounted on the specimen holder (aluminium stub) using the conductive adhesive (carbon tape). The cross-sectioned surface of the sample was observed from the top view. All samples were observed under SEM at 300x magnifications at an accelerating voltage of $20 \mathrm{kV}$.

\subsection{Determination of total plate count}

All control and irradiated flat rice noodle samples were stored at chill temperature $\left(8^{\circ} \mathrm{C}\right)$ for 7 days. Procedures of Total Plate Count (TPC) was examined according to Ghaffar et al. (2009) and Li et al. (2016) with some improvements. Noodle samples $(25 \mathrm{~g})$ with $225 \mathrm{~mL}$ of $0.1 \%$, peptone water (Oxoid CM0009) were homogenized in a stomacher bag using a stomacher machine (Lab-blender 400, Seward Laboratory, US) for $120 \mathrm{sec}$. Serial dilutions were prepared by using $0.1 \%$ peptone water. $0.1 \mathrm{~mL}$ of the appropriate dilutions were spread plated onto sterile petri dishes containing Plate Count Agar (Oxoid CM0325), and then, was incubated at $37^{\circ} \mathrm{C}$ for $48 \pm 2 \mathrm{hrs}$ in the incubator (Memmert INE-600). TPC of samples (in triplicate) were analysed for day 1,3 , 5 and 7. The colonies were counted using the Colony Counter (Galaxy 230).

\subsection{Statistical analysis}

All data obtained in this research were expressed as mean values of three individual replicates \pm standard deviation (S.D.), except data for the texture properties analysis (five individual replicates). One-way analysis of variance (ANOVA) using Minitab Statistical Software version 18.0 (Minitab Inc., USA) was performed and Tukey test was used to determine significant differences between mean values among the treatments at a significance level of $95 \%(p<0.05)$. Meanwhile, total plate count data were changed into logarithms of the number of colony forming units (CFU/g) ( $\mathrm{Li}$ et al., 2016).

\section{Results and discussion}

3.1 Effect of gamma irradiation treatment on physicochemical characteristics of flat rice noodle

The effect of gamma irradiation with different dose levels on moisture content (MC), water activity $\left(\mathrm{a}_{\mathrm{w}}\right)$, and $\mathrm{pH}$ value of flat rice noodle samples are shown in Figure 1 , Table 2 , and Table 3 respectively.

$\mathrm{MC}$ of four samples with different irradiation doses are displayed in Figure 1. Based on the results, MC of all samples was in the range of $60-66 \%$. Similarly, to the preliminary setting of samples applied to Wang et al. (2018), the MC of rice starch annealed treatment was in the range of $50-70 \%$. Results showed that MC was not significantly affected by the irradiation as there were no significant differences at ( $\mathrm{p}>0.05)$ on $11 \% \mathrm{TS},(8 \% \mathrm{TS} \&$ $3 \%$ PS) and (3\% TS \& $8 \%$ PS) of different irradiation dose levels. Such results were in accordance with those obtained by Byun et al. (1997) who observed MC of red ginseng powder was not significantly changed with the increase in gamma irradiation up to $10 \mathrm{kGy}$. Gani et al., 
Table 2. Water activity (aw) of flat rice noodles.

\begin{tabular}{lcccc}
\hline \multirow{2}{*}{ Irradiation Dose } & \multicolumn{4}{c}{ Formulation } \\
\cline { 2 - 5 } & $11 \% \mathrm{TS}$ & $11 \%$ PS & $8 \%$ TS \& 3\% PS & $3 \%$ TS \& 8\% PS \\
\hline $0 \mathrm{kGy}$ & $0.991 \pm 0.00^{\mathrm{Aa}}$ & $0.980 \pm 0.00^{\mathrm{Bb}}$ & $0.984 \pm 0.00^{\mathrm{Aab}}$ & $0.983 \pm 0.00^{\mathrm{Bab}}$ \\
$4 \mathrm{kGy}$ & $0.991 \pm 0.00^{\mathrm{Aa}}$ & $0.988 \pm 0.00^{\mathrm{Aab}}$ & $0.986 \pm 0.00^{\mathrm{Ab}}$ & $0.987 \pm 0.00^{\mathrm{ABb}}$ \\
$6 \mathrm{kGy}$ & $0.989 \pm 0.00^{\mathrm{ABa}}$ & $0.985 \pm 0.00^{\mathrm{Ab}}$ & $0.987 \pm 0.00^{\mathrm{Aab}}$ & $0.990 \pm 0.00^{\mathrm{ABa}}$ \\
$8 \mathrm{kGy}$ & $0.985 \pm 0.00^{\mathrm{Ba}}$ & $0.986 \pm 0.00^{\mathrm{Aa}}$ & $0.989 \pm 0.00^{\mathrm{Aa}}$ & $0.992 \pm 0.00^{\mathrm{Aa}}$ \\
\hline
\end{tabular}

TS: Tapioca starch, PS: Potato starch. Values with the same superscript uppercase letters within the same column are not significantly different $(\mathrm{p}>0.05)$ while values with the same superscript lowercase letters within the same row not significantly different $(\mathrm{p}>0.05)$.

Table 3. pH value of flat rice noodles.

\begin{tabular}{lcccc}
\hline \multirow{2}{*}{ Irradiation Dose } & \multicolumn{4}{c}{ Formulation } \\
\cline { 2 - 5 } & $11 \% \mathrm{TS}$ & $11 \% \mathrm{PS}$ & $8 \% \mathrm{TS} \& 3 \% \mathrm{PS}$ & $3 \% \mathrm{TS} \& 8 \% \mathrm{PS}$ \\
\hline $0 \mathrm{kGy}$ & $5.89 \pm 0.03^{\mathrm{Ba}}$ & $5.89 \pm 0.03^{\mathrm{Aa}}$ & $5.79 \pm 0.06^{\mathrm{Aa}}$ & $5.88 \pm 0.10^{\mathrm{Aa}}$ \\
$4 \mathrm{kGy}$ & $6.04 \pm 0.06^{\mathrm{Aa}}$ & $5.89 \pm 0.01^{\mathrm{Aab}}$ & $5.84 \pm 0.10^{\mathrm{Ab}}$ & $5.87 \pm 0.05^{\mathrm{Aab}}$ \\
$6 \mathrm{kGy}$ & $5.03 \pm 0.02^{\mathrm{Aa}}$ & $5.73 \pm 0.01^{\mathrm{Bd}}$ & $5.83 \pm 0.03^{\mathrm{Ac}}$ & $5.93 \pm 0.01^{\mathrm{Ab}}$ \\
$8 \mathrm{kGy}$ & $5.87 \pm 0.05^{\mathrm{Ba}}$ & $5.69 \pm 0.01^{\mathrm{Cb}}$ & $5.72 \pm 0.02^{\mathrm{Ab}}$ & $5.85 \pm 0.03^{\mathrm{Aa}}$ \\
\hline
\end{tabular}

TS: Tapioca starch, PS: Potato starch. Values with the same superscript uppercase letters within the same column are not significantly different $(\mathrm{p}>0.05)$ while values with the same superscript lowercase letters within the same row not significantly different $(\mathrm{p}>0.05)$.

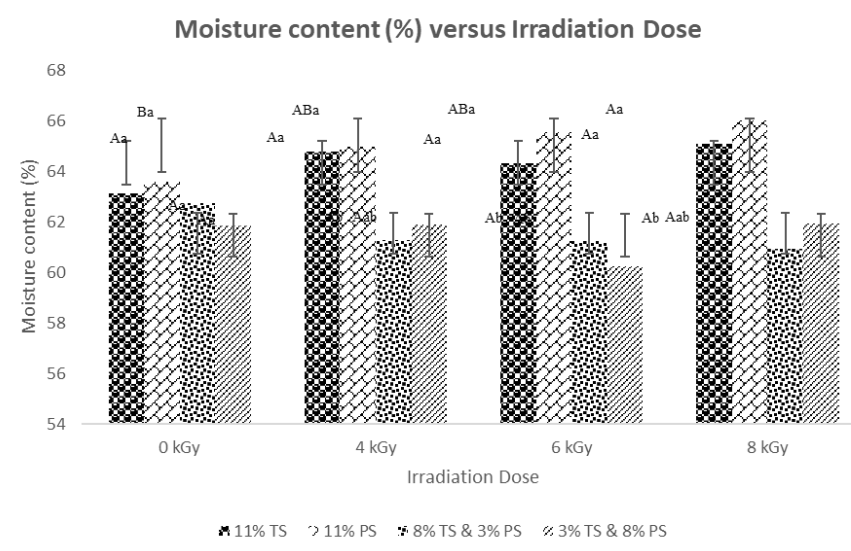

Figure 1. Moisture content of flat rice noodles. TS: Tapioca starch, PS: Potato starch. Values with the same superscript uppercase letters are not significantly different $(p>0.05)$ among irradiation doses with the same formulation. Values with the same superscript lowercase letters are not significantly different $(p>0.05)$ among flat rice noodle formulations with same irradiation dose.

(2013) also reported MC of starch extracted from lotus stem did not show any significant effect of gamma irradiation. Nevertheless, a study has shown the opposite results where a higher dose (6 kGy) of irradiation causes more rapid loss of moisture in apples (Wang and Chao, 2003). However, MC between samples with the same irradiation dose, except $0 \mathrm{kGy}$ irradiation showed significant difference $(\mathrm{p}<0.05) .11 \%$ TS and $11 \%$ PS alone had significantly increased in MC compared to flat rice noodles contained both TS and PS at 4-8 kGy irradiation. Base on the result, a similar finding was reported that increasing amylose resulted in increasing MC (Widjajaseputra, 2012). PS has higher amylose content than TS which agreed by Breuninger et al.
(2009) as attributed in flat rice noodles. A combination of these two starches might influence the $\mathrm{MC}$ of flat rice noodles. But there is no report of the relevant literature describes a study of effects on the combination between PS and TS.

Table 2 shows the results of water activity, where there were differ $(\mathrm{p}<0.05)$ statistically among the irradiation doses as well as the type of formulation, except ( $8 \%$ and $3 \%$ PS) at different doses and types of formulation at $8 \mathrm{kGy}$ irradiation dose. In contrast with the results obtained for maize (Zea mays) genotypes seeds, water activity did not change significantly with the increasing of gamma irradiation dose (Yadav and Singh, 2013). Byun et al. (2000) stated that the water activity of squid was not altered with the use of gamma irradiation. However, Aquino et al. (2010) explained that changes in the water activity caused by gamma irradiation doses were due to the water radiolysis after the irradiation process which leads to the formation of highly reactive free radicals. Flat rice noodle samples had mean water activity value ranged between 0.983 and 0.992 which reported slightly higher value in comparison to 0.979 which obtained by Li et al. (2011) for control noodle. This indicates that high water activity is sufficient for the growth of microbial. According to Qing (2016), due to more free water available for the growth of microorganism activity, high water activity in noodles can accelerate the spoilage process.

The $\mathrm{pH}$ value of four samples with different irradiation doses are presented in Table 3 . The $\mathrm{pH}$ values for all samples ranging from 5.69 to 6.04 . This is because rice noodles made from rice and water 
contribute to an initial $\mathrm{pH}$ of 7 (neutral) condition ( $\mathrm{Li}$ et al., 2015). Tapioca starch contribued to the lower $\mathrm{pH}$ value due to its naturally present low $\mathrm{pH}$. Nearly the same initial $\mathrm{pH}$ value was observed by Li et al. (2011) ranging (6.21-6.48) in fresh noodles. Based on the results obtained, there were significant differences $(p<0.05)$ in a $\mathrm{pH}$ value of $11 \%$ TS and $11 \%$ PS at different irradiation doses. The $\mathrm{pH}$ value was observed to decrease as the dose of irradiation increased. Similarly, $\mathrm{pH}$ values in all types of kidney bean starches were also reported to decrease as the irradiation dose increased from $0 \mathrm{kGy}$ to $20 \mathrm{kGy}$ (Gani et al., 2012). The results are in agreement with those found by Gani et al. (2013), they reported that the breakdown of starch molecules by the action of free radicals caused an increase of carboxyl content in irradiated starch. The decrease in $\mathrm{pH}$ value was due to the formation of degradation products (carboxylic acids) during irradiation which also increases the carboxyl content of samples. The $\mathrm{pH}$ value observed on $11 \%$ PS was found to be the most affected as the irradiation doses increased. In contrast, finding obtained by Romano et al., (2016) shows neither raw, uncooked nor exposed to treatment, PS contain high $\mathrm{pH}$ value (7.26) compared to TS (4.86), which showed that it has low acid content.

\subsection{Cooking properties}

The effect of gamma irradiation with different doses on cooking yield and cooking loss of flat rice noodles is shown in Figure 2 and Figure 3 respectively. Based on Figure 2 , there were significantly different $(p<0.05)$ in cooking yield among formulation at different irradiation dose levels. The cooking yield was observed to decrease as the irradiation dose increased where control (0 kGy) samples showed the highest value of cooking yield compared to the rest of the irradiated samples. The ranges of cooking yield for control samples were from $153.91 \%(11 \%$ TS) to 161.85 (11\% PS) which were slightly lower from the value obtained by Qazi et al. (2014) who reported that noodles from pure PS had rehydration value of $168.50 \%$. According to Chin et al. (2012), high cooking yield determines the ability of water absorption in noodles during the cooking process and gelatinisation process of starch which might help in increasing the weight of noodles after cooking. However, gamma irradiation caused decreases in the cooking yield of flat rice noodles. This is because, gamma irradiation breakdown starch molecular to form low molecular weight fractions and degrades the starch structure (El Saadany et al., 1979; Gani et al., 2013). By contrast, Sirisoontaralak and Noomhorm (2006) study, found that water absorption increased after irradiation. Besides that, the cooking yield of flat rice noodles contained PS significantly $(p<0.05)$ increased compared to flat rice noodles contained TS alone. This may due to the differences in the swelling power and pasting properties of the starches (Qazi et al., 2014).

\section{Cooking yield (\%) versus Formulation}

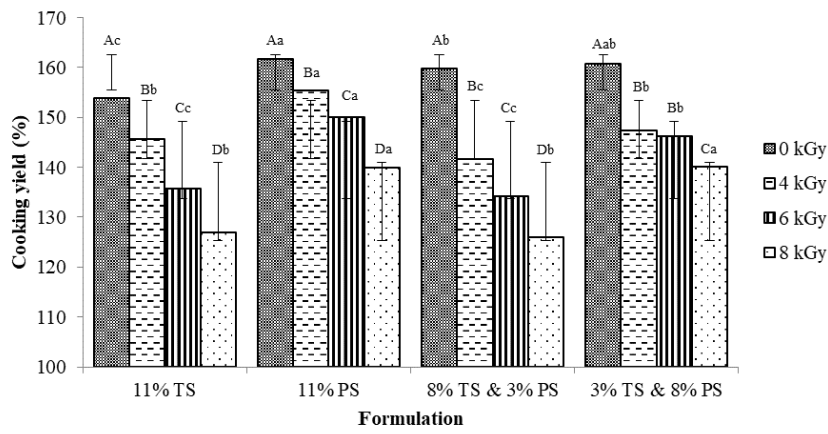

Figure 2. Cooking yield for flat rice noodles. TS: Tapioca starch, PS: Potato starch. Values with the same superscript uppercase letters are not significantly different $(p>0.05)$ among irradiation doses with the same formulation. Values with the same superscript lowercase letters are not significantly different $(p>0.05)$ among flat rice noodle formulations with same irradiation dose.

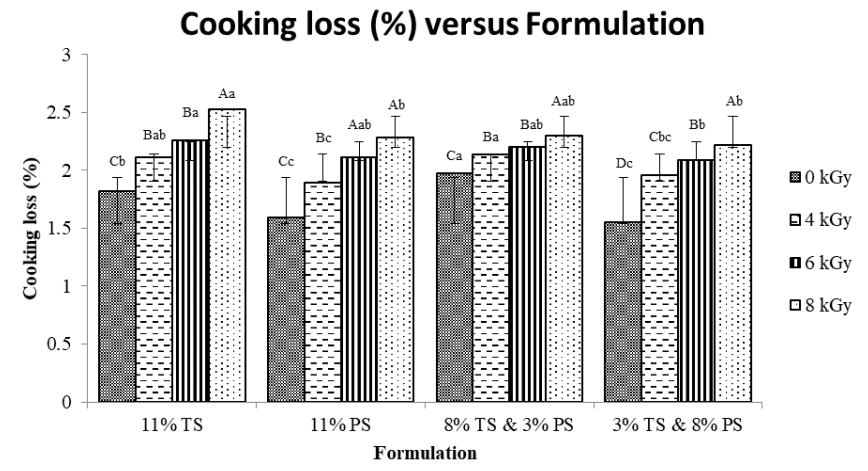

Figure 3. Cooking loss for flat rice noodles. TS: Tapioca starch, PS: Potato starch. Values with the same superscript uppercase letters are not significantly different $(p>0.05)$ among irradiation doses with the same formulation. Values with the same superscript lowercase letters are not significantly different $(\mathrm{p}>0.05)$ among flat rice noodle formulations with same irradiation dose.

Cooking loss is a term used for the particles that leaked from the noodles into cooking water (Chin et al., 2012). It is undesirable to have a high value of cooking loss because it shows that noodles had low tolerance during cooking, a greater amount of solubilized starch present and caused noodles to have sticky texture (Sandhu et al., 2010; Thomas et al., 2014). Sandhu et al. (2010) also reported that rice noodles had a cooking loss of $1.53 \%$, which slightly lower from the range of cooking loss obtained for control samples in this research $(1.55-1.98 \%)$. There was a significant $(\mathrm{p}<0.05)$ increase in cooking loss among samples at different irradiation dose levels as well as significant difference $(p<0.05)$ observed in the different formulation of flat rice noodles samples as shown in Figure 3. According to Gani et al. (2012), irradiation contributes to the damage of starch 
into simpler molecules form like dextrins, maltose and other sugars that have a higher affinity for water than starch.

\subsection{Colour of flat rice noodle}

The effect of gamma irradiation with different doses on colour values of $\mathrm{L}^{*}, \mathrm{a}^{*}$ and $\mathrm{b}^{*}$ for flat rice noodles are shown in Figure 4, Figure 5, and Figure 6 respectively.

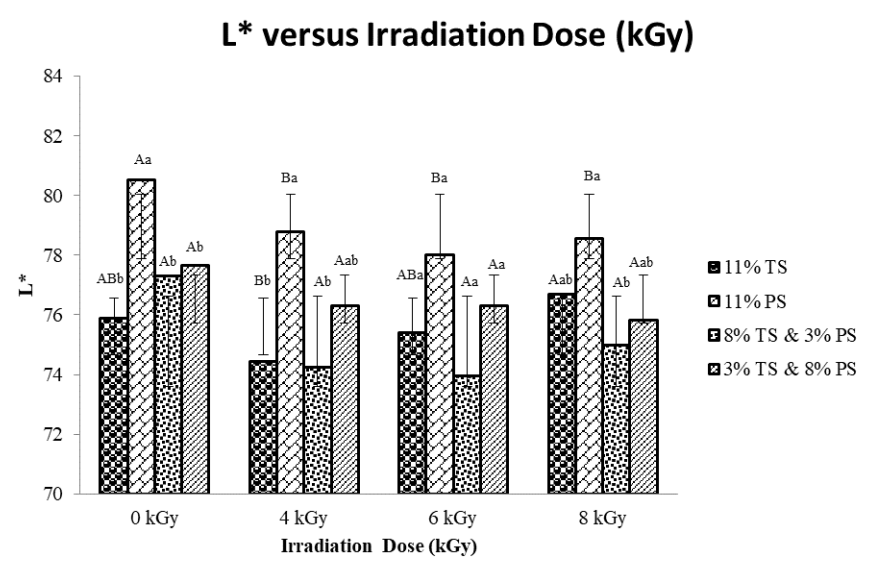

Figure 4. Colour value of $\mathrm{L}^{*}$ for flat rice noodles. TS: Tapioca starch, PS: Potato starch. Values with the same superscript uppercase letters are not significantly different $(p>0.05)$ among irradiation doses with the same formulation. Values with the same superscript lowercase letters are not significantly different $(\mathrm{p}>0.05)$ among flat rice noodle formulations with same irradiation dose.

Resultant colour values of flat rice noodles samples treated with different irradiation dose levels are presented in Figure 5. $\mathrm{L}^{*}$ value is a measurement of lightness (0; dark - 100; white). Based on the results obtained, all samples appeared to have light colour closer to white where the value of $\mathrm{L}^{*}$ was 74 and above. According to Thomas et al. (2014), fresh noodles shall retain a white coloured appearance. There was a slight decrease in $L^{*}$ value of flat rice noodles samples with increased dose levels where irradiated samples showed darken in colour compared to control samples. A study found that gamma irradiation at any dose levels did not give a significant difference in the $\mathrm{L}^{*}$ value of potato starches (Teixeira et al., 2015). This research contradicts the present findings. Nonetheless, results obtained agreed with the findings of Mir et al. (2015) who reported that all brown rice varieties showed decreased in $\mathrm{L}^{*}$ (lightness) as irradiation dose increase up to $10 \mathrm{kGy}$. The same goes to result obtained by Byun et al. (1997) for red ginseng powder up to $10 \mathrm{kGy}$. The enzymatic and non-enzymatic darkening reactions by high water content in fresh noodles could be accelerated by high dose of irradiation which leads to slight changes in colour (Lacroix et al., 2004; Asenstorfer et al., 2010).
Moreover, flat rice noodles contained PS showed higher $\mathrm{L}^{*}$ compared to contained TS. This is because high amylose concentration provides noodles with bright colour and low bulk density due to their ability to reduce swelling powder (Ahmed et al., 2016). Generally, rice flour, tapioca starch and potato starch containing amylose at 16-20\% (Etsuko et al., 2016), 17\% (Riaz, 2016) and 11.9-20.1\% (Talja et al. 2008) respectively.

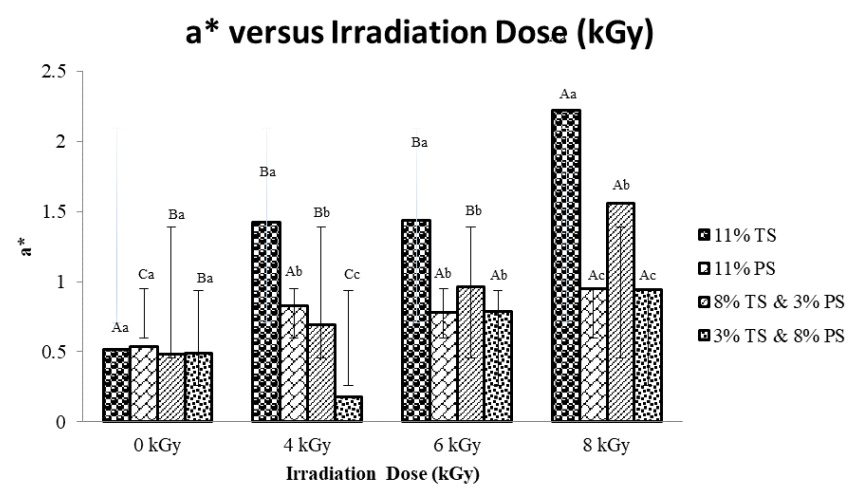

Figure 5. Colour value of $\mathrm{a}^{*}$ for flat rice noodles. TS: Tapioca starch, PS: Potato starch. Values with the same superscript uppercase letters are not significantly different $(p>0.05)$ among irradiation doses with the same formulation. Values with the same superscript lowercase letters are not significantly different $(\mathrm{p}>0.05)$ among flat rice noodle formulations with same irradiation dose.

There were significant increases $(\mathrm{p}<0.05)$ in $\mathrm{a}^{*}$ value of flat rice noodle samples irradiated with different dose levels except $11 \%$ PS sample as shown in Figure 5. Colour of $a^{*}$ value indicates the degree of redness $(+a)$ to greenness $(-a)$. Flat rice noodle samples increased in $a^{*}$ value after being irradiated at the $8 \mathrm{kGy}$. Similarly, there was an increase of $a^{*}$ value as an irradiation dose increased in brown rice (Mir et al., 2015). This can be supported by Teixeira et al. (2015) who reported parameter $\mathrm{a}^{*}$ increase with the doses on potato starches. Meanwhile, significant differences $(\mathrm{p}<0.05)$ were also observed in $a^{*}$ value among flat rice noodles samples. However, the differences in $a^{*}$ value of flat rice noodles samples could not be differentiated visually.

Figure 6 showed $b^{*}$ value of flat rice noodles samples with different gamma irradiation dose levels. Colour value of $b^{*}$ represents the degree of yellowness $(+b)$ to blueness $(-b)$. Results showed that $b^{*}$ value of flat rice noodles samples was slightly increased at $8 \mathrm{kGy}$. According to Jianming (1998), fresh noodles when irradiated up to $10 \mathrm{kGy}$ turns yellowed slightly. Meanwhile, Sirisoontaralak and Noomhorm (2006) stated that due to the breakdown of glycosidic and peptide linkages when irradiation dose increased resulted in increased colour value. There were no significant differences $(p<0.05)$ observed among flat rice noodle samples. Thus, gamma irradiation in the applied doses 
changed the colour of flat rice noodles samples with different types of starch.

\section{b* versus Irradiation Dose (kGy)}

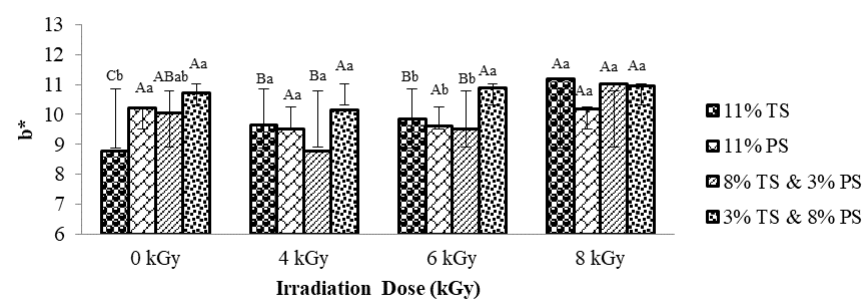

Figure 6. Colour value of $b^{*}$ for flat rice noodles. TS: Tapioca starch, PS: Potato starch. Values with the same superscript uppercase letters are not significantly different $(p>0.05)$ among irradiation doses with the same formulation. Values with the same superscript lowercase letters are not significantly different $(\mathrm{p}>0.05)$ among flat rice noodle formulations with same irradiation dose.

\subsection{Textural properties}

The effect of gamma irradiation with different doses on hardness and breaking length of flat rice noodles is shown in Table 4 and Table 5 respectively.

The hardness of four flat rice noodle samples with different irradiation doses were compared in Table 4. The hardness values among formulations observed did not differ significantly $(\mathrm{p}>0.05)$; however, was affected by the irradiation doses. It was significantly lower in hardness values among irradiated samples if compared to control flat rice noodles samples. The highest hardness in non-irradiation flat rice noodles was observed in $11 \%$ PS $(2.72 \mathrm{~N})$, followed by $3 \%$ TS \& $8 \%$ PS $(2.71 \mathrm{~N}), 11 \%$ TS $(2.61 \mathrm{~N})$ and $8 \%$ TS \& $3 \%$ PS $(2.32 \mathrm{~N})$ formulation. The value of hardness was proportional to the amylose content in the formulation. After treatment of $8 \mathrm{kGy}$ gamma irradiation, the hardness of flat rice noodles among the formulation reduced to $1.99 \mathrm{~N}, 2.08 \mathrm{~N}, 1.92 \mathrm{~N}$ and $1.55 \mathrm{~N}$ for $11 \%$ PS, $3 \%$ TS \& $8 \%$ PS, $11 \%$ TS and $8 \%$ TS \& 3\% PS formulation respectively. The results showed that the increase in gamma irradiation dose will decrease the hardness value. Sandhu et al. (2010) stated that amylose content plays a major role in noodle's texture. It was proven that high amylose content appeared to be positively related to the hardness of noodles (Jeong et al., 2016). This is because amylose and amylopectin might go through degradation or modification during irradiation which loosens the compact structure of starch granules which contributes to the differences in hardness (Mir et al., 2015). The same trend can be observed in beetroots where the lowest hardness was obtained at a dose of $10 \mathrm{kGy}$ (Nayak et al., 2006). They further stated that gamma irradiation caused softening of the tissue. This observation was in agreement with the work of Jianming (1998) who reported that hardness of the fresh noodles changed according to the absorbed dose. Similarly, Noomhorm et al. (2005) stated that the breakdown of the starch molecule had been encouraged by gamma irradiation.

On the contrary, the breaking length of flat rice noodle samples increased when the dose level increased as shown in Table 5. Control flat rice noodle samples showed significantly lower in breaking length value compared to irradiated flat rice noodle samples. It can be seen clearly when dose levels increased, values of breaking length also increased. Those trend of result are in agreement with Wan Zunairah et al. (2019) on the study on watery spinach yellow noodles but, in disagreement with other previous studies. Research

Table 4. Hardness of flat rice noodles.

\begin{tabular}{lcccc}
\hline \multirow{2}{*}{ Irradiation Dose } & \multicolumn{4}{c}{ Hardness of sample $(\mathrm{N})$} \\
\cline { 2 - 5 } & $11 \% \mathrm{TS}$ & $11 \% \mathrm{SPS}$ & $8 \%$ TS \& 3\% SPS & $3 \%$ TS \& 8\% SPS \\
\hline $0 \mathrm{kGy}$ & $2.61 \pm 0.06^{\mathrm{Aa}}$ & $2.72 \pm 0.73^{\mathrm{Aa}}$ & $2.32 \pm 0.54^{\mathrm{Aa}}$ & $2.71 \pm 0.58^{\mathrm{Aa}}$ \\
$4 \mathrm{kGy}$ & $1.97 \pm 0.31^{\mathrm{Ba}}$ & $2.10 \pm 0.23^{\mathrm{Aa}}$ & $2.13 \pm 0.61^{\mathrm{Aa}}$ & $1.55 \pm 0.35^{\mathrm{Ba}}$ \\
$6 \mathrm{kGy}$ & $1.99 \pm 0.16^{\mathrm{Ba}}$ & $2.09 \pm 0.51^{\mathrm{Aa}}$ & $2.13 \pm 0.50^{\mathrm{Aa}}$ & $1.78 \pm 0.07^{\mathrm{Ba}}$ \\
$8 \mathrm{kGy}$ & $1.92 \pm 0.47^{\mathrm{Ba}}$ & $1.99 \pm 0.28^{\mathrm{Aa}}$ & $1.55 \pm 0.33^{\mathrm{Aa}}$ & $2.08 \pm 0.23^{\mathrm{ABa}}$ \\
\hline
\end{tabular}

TS: Tapioca starch, PS: Potato starch. Values with the same superscript uppercase letters within the same column are not significantly different $(\mathrm{p}>0.05)$ while values with the same superscript lowercase letters within the same row not significantly different $(\mathrm{p}>0.05)$.

Table 5. Breaking length of flat rice noodles.

\begin{tabular}{lcccc}
\hline \multirow{2}{*}{ Irradiation Dose } & \multicolumn{4}{c}{ Breaking length of sample $(\mathrm{mm})$} \\
\cline { 2 - 5 } & $11 \% \mathrm{TS}$ & $11 \% \mathrm{PS}$ & $8 \%$ TS \& 3\% PS & $3 \%$ TS \& 8\% PS \\
\hline $0 \mathrm{kGy}$ & $4.29 \pm 0.98^{\mathrm{Ba}}$ & $2.19 \pm 0.46^{\mathrm{Bb}}$ & $3.24 \pm 0.24^{\mathrm{Bab}}$ & $2.92 \pm 0.41^{\mathrm{Bb}}$ \\
$4 \mathrm{kGy}$ & $5.71 \pm 0.89^{\mathrm{ABa}}$ & $2.67 \pm 0.38^{\mathrm{ABc}}$ & $3.82 \pm 0.50^{\mathrm{ABb}}$ & $3.53 \pm 0.57^{\mathrm{ABbc}}$ \\
$6 \mathrm{kGy}$ & $6.13 \pm 0.43^{\mathrm{Aa}}$ & $2.53 \pm 0.23^{\mathrm{ABd}}$ & $4.63 \pm 0.79^{\mathrm{Ab}}$ & $3.57 \pm 0.44^{\mathrm{ABc}}$ \\
$8 \mathrm{kGy}$ & $5.07 \pm 0.86^{\mathrm{ABa}}$ & $2.94 \pm 0.33^{\mathrm{Ab}}$ & $4.55 \pm 0.87^{\mathrm{Aa}}$ & $4.25 \pm 1.13^{\mathrm{Aab}}$ \\
\hline
\end{tabular}

TS: Tapioca starch, PS: Potato starch. Values with the same superscript uppercase letters within the same column are not significantly different $(\mathrm{p}>0.05)$ while values with the same superscript lowercase letters within the same row not significantly different $(\mathrm{p}>0.05)$. 
conducted by Köksel et al. (1996) who reported that gamma irradiation doses did affect durum wheat where it altered the gluten and starch components especially at high levels of treatment. They further reported that when gluten damage, it caused the dough to lose strength and reduce breaking length value. Meanwhile, the use of PS in flat rice noodle samples showed lower breaking length value compared to flat rice noodle samples contained TS. PS was believed to contain high amylose compared to TS. Contrary with the finding from Fari et al. (2011) and Guo et al. (2003) who reported that high tensile strength caused from high amylose content as cited in Thomas et al. (2014). This is supported by $\mathrm{Lu}$ and Collado (2019) who explained that higher amylose content gives greater elastic properties to noodles. However, there were no related studies found on the relationship between PS and TS in the production of rice noodles with tensile tests.

\subsection{Morphological structure of cross section in flat rice noodle}

Scanning electron microscopy (SEM) photographs of $11 \%$ TS (Tapioca starch), 11\% PS (Potato starch), (8\%
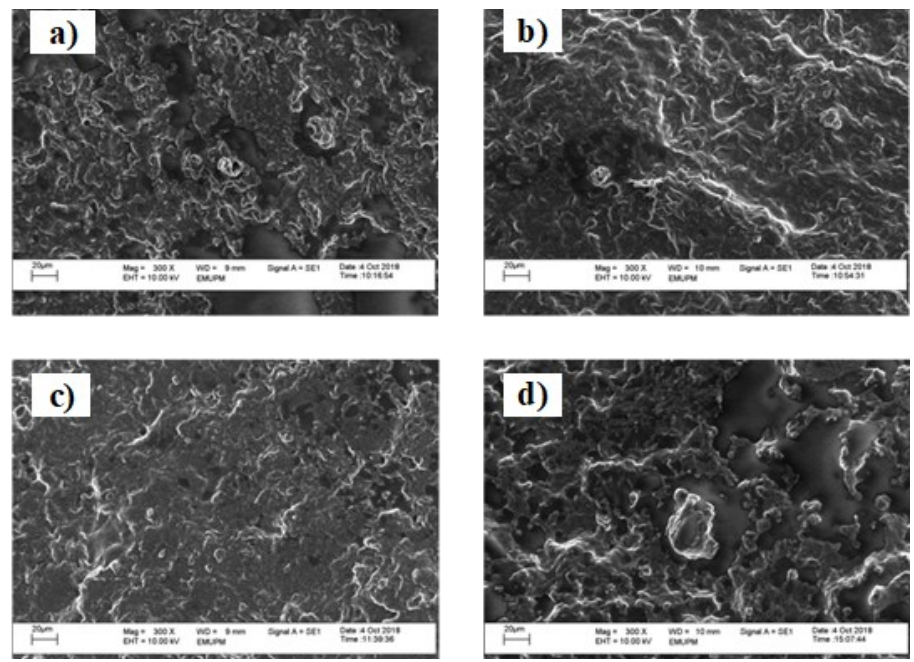

A) $11 \% \mathrm{TS}$
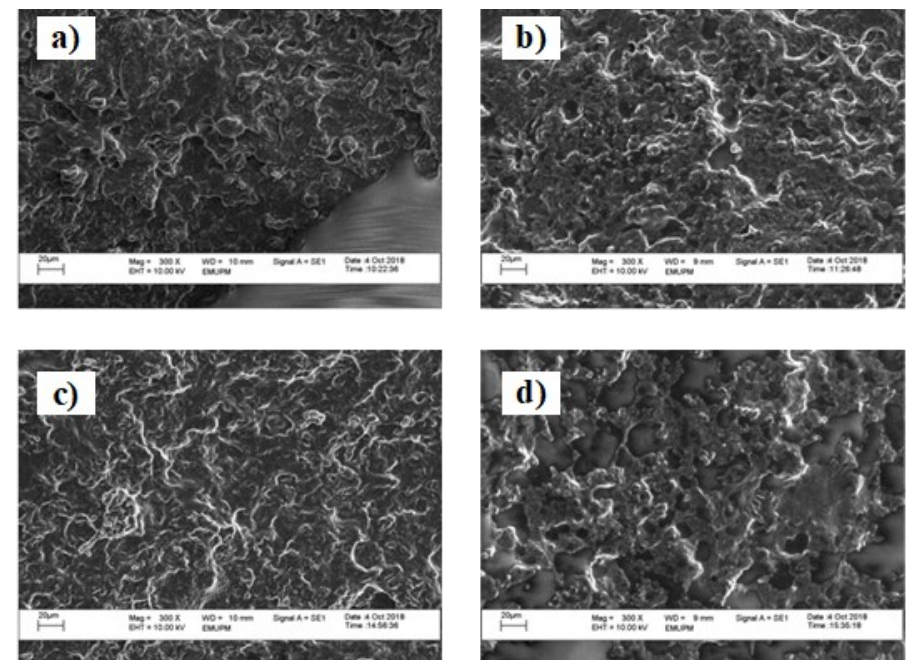

C) $8 \% \mathrm{TS} \& 3 \% \mathrm{PS}$
TS \& 3\% PS) and (3\% TS \& 8\% PS) samples are shown in Figure 7.

Results showed that there was no presence of starch granules observed for each flat rice noodle samples in each dose of irradiation. Similarly, Kasemsuwan et al. (1998) reported that starch granules were gelatinised and ruptured as there were no intact granules observed in cross section of the clear noodles. They further stated that this was due to the retrogradation process. Starch retrogradation occurs during cooling where amylose and amylopectin macromolecules in gelatinised began to reassociated and united with swollen starch in an ordered structure (Mason, 2009; Bao and Bergman, 2018) These process might further being modified where the starch granules are ruptured. Thus, the effect of gamma irradiation was not able to be observed and compared due to the absence of on starch granules in both starches; TS and PS.

\subsection{Microbiological quality of flat rice noodles}

The effect of gamma irradiation with different dose
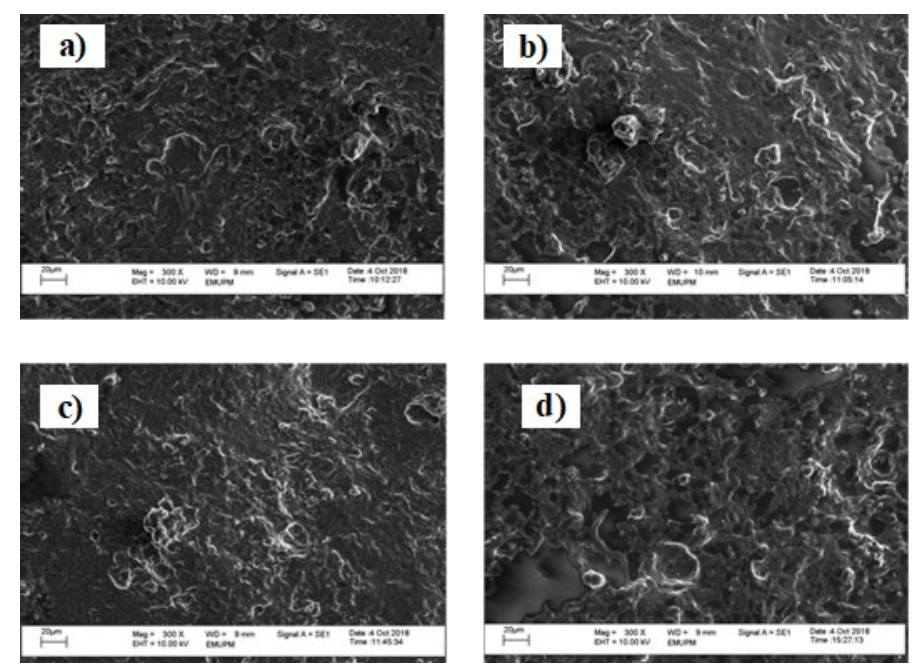

B) $11 \% \mathrm{PS}$
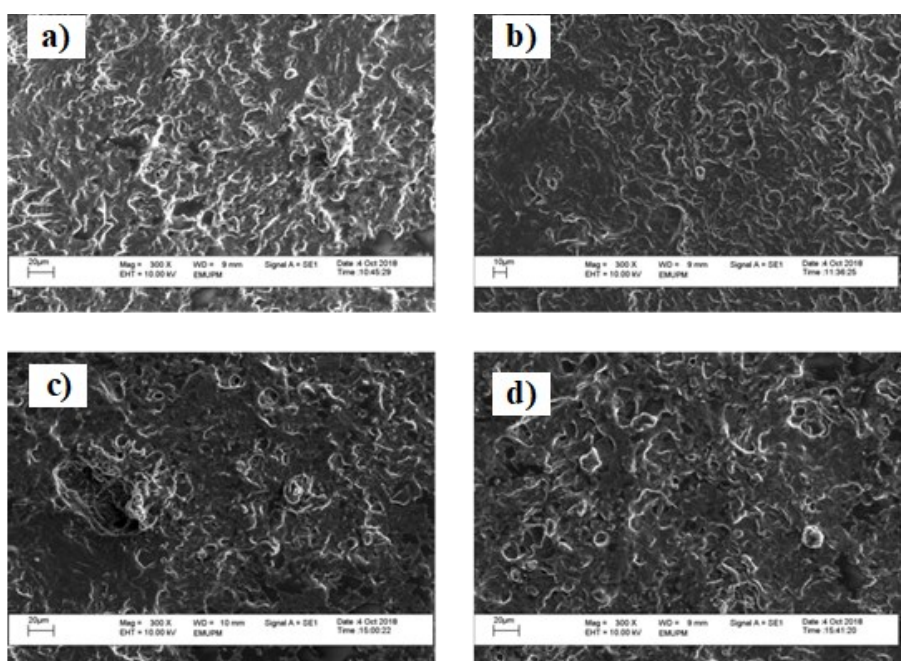

D) $3 \% \mathrm{TS} \& 8 \% \mathrm{PS}$

Figure 7. Morphological structures cross section of flat rice noodles A) $11 \%$ TS, B) $11 \%$ PS, C) $8 \%$ TS \& 3\% PS and D) 3\% TS \& $8 \%$ PS samples at different dose of irradiation at a) $0 \mathrm{kGy}$; b) $4 \mathrm{kGy}$; c) $6 \mathrm{kGy}$; d) $8 \mathrm{kGy}$ at 300x magnification. 
Table 6. Total plate count (TPC) of flat rice noodles after stored at $8^{\circ} \mathrm{C}$ for 7 days.

\begin{tabular}{lcccc}
\hline Irradiation Dose & \multicolumn{3}{c}{ Total Colony Count $(\log$ CFU/g) } \\
\cline { 2 - 5 } $11 \%$ TS 0 kGy & Day 1 & Day 3 & Day 5 & Day 7 \\
$11 \%$ TS 4 kGy & $4.18 \pm 0.08^{\mathrm{Aa}}$ & $7.11 \pm 0.01^{\mathrm{Ab}}$ & Spoiled & Spoiled \\
$11 \%$ TS 6 kGy & $<1^{\mathrm{Ba}}$ & $3.20 \pm 0.17^{\mathrm{Ba}}$ & $4.23 \pm 0.03^{\mathrm{Aa}}$ & $4.67 \pm 0.03^{\mathrm{Aab}}$ \\
$11 \%$ TS 8 kGy & $<1^{\mathrm{Ba}}$ & $<1^{\mathrm{Ca}}$ & $1.20 \pm 2.08^{\mathrm{Ba}}$ & $2.20 \pm 1.91^{\mathrm{ABa}}$ \\
$11 \%$ PS, 0 kGy & $<1^{\mathrm{Ba}}$ & $<1^{\mathrm{Ca}}$ & $<1^{\mathrm{Ba}}$ & $<1^{\mathrm{Ba}}$ \\
$11 \%$ PS 4 kGy & $3.66 \pm 0.10^{\mathrm{Ab}}$ & $7.24 \pm 0.08^{\mathrm{Aa}}$ & Spoiled & Spoiled \\
$11 \%$ PS 6 kGy & $<1^{\mathrm{Ba}}$ & $3.30 \pm 0.30^{\mathrm{Ba}}$ & $3.58 \pm 0.48^{\mathrm{Ba}}$ & $4.23 \pm 0.08^{\mathrm{Ac}}$ \\
$11 \%$ PS 8 kGy & $<1^{\mathrm{Ba}}$ & $2.00 \pm 1.73^{\mathrm{BCa}}$ & $2.39 \pm 2.16^{\mathrm{BCa}}$ & $2.65 \pm 2.30^{\mathrm{ABa}}$ \\
$8 \%$ TS \& 3\% PS 0 kGy & $4.30 \pm 0.08^{\mathrm{Aa}}$ & $7.04 \pm 0.05^{\mathrm{Ab}}$ & $<1^{\mathrm{Ca}}$ & $<1^{\mathrm{Ba}}$ \\
$8 \%$ TS \& 3\% PS $4 \mathrm{kGy}$ & $<1^{\mathrm{Ba}}$ & $3.58 \pm 0.17^{\mathrm{Ba}}$ & $4.02 \pm 0.08^{\mathrm{Aa}}$ & $4.78 \pm 0.03^{\mathrm{Aa}}$ \\
$8 \%$ TS \& 3\% PS 6 kGy & $<1^{\mathrm{Ba}}$ & $<1^{\mathrm{Ca}}$ & $3.32 \pm 0.28^{\mathrm{Ba}}$ & $3.86 \pm 0.07^{\mathrm{Ba}}$ \\
$8 \%$ TS \& 3\% PS 8 kGy & $<1^{\mathrm{Ba}}$ & $<1^{\mathrm{Ca}}$ & $<1^{\mathrm{Ca}}$ & $<1^{\mathrm{Ca}}$ \\
$3 \%$ TS \& 8\% PS 0 kGy & $3.83 \pm 0.13^{\mathrm{Ab}}$ & $7.04 \pm 0.02^{\mathrm{Ab}}$ & Spoiled & Spoiled \\
$3 \%$ TS \& 8\% PS 4 kGy & $<1^{\mathrm{Ba}}$ & $2.33 \pm 2.03^{\mathrm{Ba}}$ & $4.19 \pm 0.11^{\mathrm{Aa}}$ & $4.58 \pm 0.02^{\mathrm{Ab}}$ \\
$3 \%$ TS \& 8\% PS 6 kGy & $<1^{\mathrm{Ba}}$ & $1.00 \pm 1.73^{\mathrm{Ba}}$ & $2.10 \pm 1.83^{\mathrm{BCa}}$ & $3.23 \pm 0.40^{\mathrm{Ba}}$ \\
$3 \%$ TS \& 8\% PS 8 kGy & $<1^{\mathrm{Ba}}$ & $<1^{\mathrm{Ba}}$ & $<1^{\mathrm{Ca}}$ & $<1^{\mathrm{Ca}}$ \\
\hline
\end{tabular}

TS: Tapioca starch, PS: Potato starch. Values with the same superscript uppercase letters within the same column are not significantly different $(\mathrm{p}>0.05)$ while values with the same superscript lowercase letters within the same row not significantly different ( $\mathrm{p}>0.05)$.

levels on a total plate count of flat rice noodles after stored at chill temperature $\left(8^{\circ} \mathrm{C}\right)$ are shown in Table 6.

The $\log \mathrm{CFU} / \mathrm{g}$ for each flat rice noodle sample was calculated at 2 days interval starting from day 1 to day 7. According to Jensel et al. $\log 6 \mathrm{CFU} / \mathrm{g}$ is considered to be an unacceptable level (as cited in Ghaffar et al., 2009). TPC results showed that control flat rice noodle samples for all formulation started to spoil on day 3 onwards while irradiated flat rice noodle samples were able to withstand lower microbial load up to days 7 . There were significant $(\mathrm{p}<0.05)$ increase in TPC for all flat rice noodle samples during 7 days storage at different dose levels while no significant difference ( $p>0.05$ ) observed on irradiated samples at the same dose levels upon storage. TPC for irradiated flat rice noodle samples ( $4 \mathrm{kGy}$ to $6 \mathrm{kGy}$ ) stored at $8^{\circ} \mathrm{C}$ did not exceed the selected deterioration limits. At the irradiation dose level of $8 \mathrm{kGy}$, there was no presence of colony in the flat rice noodle samples for all formulations until the end of storage day. Jianming (1998) on his finding found that wet noodles irradiated at $8 \mathrm{kGy}$ can be stored at room temperature up to 10 days or more. In addition, higher dose levels also showed the lower log CFU/g in flat rice noodle samples. Control flat rice noodle samples were observed to prolonged lag phased for microbial growth a day only even when stored at a lower temperature.

\section{Conclusion}

Effect of gamma irradiation doses (4, 6 and 8 kGy) on physicochemical characteristics and microbiological quality on flat rice noodle with two different starch combinations was discussed in this research. Gamma irradiation had some changes in physicochemical properties including cooking quality, texture, and colour of flat rice noodle where the increase in dose levels decreased $\mathrm{pH}$ value, cooking yield, lightness, and hardness of noodles and increased cooking loss, greenness, yellowness and breaking length of noodles. Moisture content and water activity were not significantly affected by irradiation dosage. Irradiation showed no effects on the morphological structure of flat rice noodle. Other than that, result in this research also highlighted that gamma irradiation dosage up to $4 \mathrm{kGy}$ was proven to impart a lower microbial growth. Potato starch gave higher cooking yield, lower cooking loss, more lightness, and better hardness on flat rice noodle than tapioca starch. Thus, the outcome of this research suggested that gamma irradiation up to $8 \mathrm{kGy}$ was effective in prolonging shelf-life if flat rice noodle. However, it induced the degradation and modification of amylose and amylopectin in starch and slightly affect the properties of flat rice noodle.

\section{Conflict of Interest}

The authors declare no conflict of interest.

\section{Acknowledgments}

The authors would like to thank Agency Nuclear 
Malaysia (Dengkil) for providing the use of the irradiation facility. The research work was funded by the Putra Grant UPM (Grant No. 9550600).

\section{References}

AACC. (2000). Approved Methods of the American Association of Cereal Chemists. AACC 44-15.02 Moisture-Air-Oven Methods, St. Paul, MN: American Association of Cereal Chemists.

Ahmed, I., Qazi, I.M., Li, Z. and Ullah, J. (2016). Rice noodles: Materials, processing and quality evaluation. Proceedings of the Pakistan Academy of Sciences, 53(3B), 215-238.

AOAC. (2000). The Association of Official Analytical Chemists. Gaithersburg, USA: AOAC.

Aquino, S., Gonçalez, E., Rossi, M.H.W., Nogueira, J.H.C., Reis, T.A. and Côrrea, B. (2010). Evaluation of fungal burden and aflatoxin presence in packed medicinal plants treated by gamma radiation. Journal of Food Protection, 73(5), 932-937. https:// doi.org/10.4315/0362-028X-73.5.932

Asenstorfer, R.E., Appelbee, M.J. and Mares, D.J. (2010). Impact of protein on darkening in yellow alkaline noodles. Journal of Agricultural and Food Chemistry, 58(7), 4500-4507. https:// doi.org/10.1021/jf904232p

Bao, J. and Bergman, C.J. (2018). Chapter 10 - Rice Flour and Starch Functionality. In Sjoo, M. and Nilsson, L. (Eds.) Starch in Food. Structure, Function and Applications. $2^{\text {nd }}$ ed., p. 373-419. USA: Woodhea Publishing. https://doi.org/10.1016/B9780-08-100868-3.00010-X

Breuninger, W.F., Piyachomkwan, K. and Sriroth, K. (2009). Tapioca/cassava starch : production and use. In BeMiller, J. and Whistler, R. (Eds.). Starch. Chemistry and Technology. $3^{\text {rd }}$ ed., p. 541-586. USA: Academic Press. https://doi.org/10.1016/B978 -0-12-746275-2.00012-4

Byun, M.-W., Lee, K.-H., Kim, D.-H., Kim, J.-H., Yook, H.-S. and Ahn, H.-J. (2000). Effects of gamma radiation on sensory qualities, microbiological and chemical properties of salted and fermented squid. Journal of Food Protection, 63(7), 934-939. https:// doi.org/10.4315/0362-028X-63.7.934

Byun, M.-W., Yook, H.-S., Kwon, O.-J. and Kang, I.-J. (1997). Effects of gamma irradiation on physicochemical properties of Korean red ginseng powder. Radiation Physical and Chemistry Journal, 49(4), 483-489. https://doi.org/10.1016/S0969-806X (96)00153-3

Chin, C.K., Huda, N. and Yang, T.A. (2012). Incorporation of surimi powder in wet yellow noodles and its effects on the physicochemical and sensory properties. International Food Research Journal, 19(2), 701-707.

El Saadany, R.M.A., Foda, Y.H. and El Saadany, F.M. (1979). Improving of Egyptian rice by means of gamma irradiation. Starch, 31(7), 230-234. https:// doi.org/10.1002/star.19790310706

Etsuko, A., Kanae, A., Noriaki, A., Makoto, T. and Shigeki, H. (2016). Review characteristic of rice flour suitable for the production of rice flour bread containing gluten and methods of reducing the cost of producing rice flour. Japan Agricultural Research Quarterly, 50(1), 23-31.

Fari, M.J.M., Rajapaksa, D. and Ranaweera, K.K.D.S. (2011). Quality characteristics of noodles made from selected varieties of Sri Lankan rice with different physicochemical characteristics. Journal of National Science Foundation of Sri Lanka, 39(1), 53-60. https://doi.org/10.4038/jnsfsr.v39i1.2923

Finagenov, O.M. and Glagovsky, V.B. (2005). Assessment of reliability of offshore marine hydraulic structures under seismic impacts presented at the Proceedings of the Fifteenth International Offshore and Polar Engineering Conference, 19-24 June 2005. Seoul, Korea.

Food Irradiation and Processing Alliance (FIPA) an affiliate of the International Irradiation Association (2006). Food irradiation question and answer. Retrieved from FIPA website: http:// www.foodirradiation.org/PDF/FIPA QandA.pdf

Fu, B.X. (2008). Asian noodles: History, classification, raw materials, and processing. Food Research International, 41(9), 888-902. https:// doi.org/10.1016/j.foodres.2007.11.007

Gani, A., Bashir, M., Wani, S.M. and Masoodi, F.A. (2012). Modification of bean starch by $\gamma$-irradiation: Effect on functional and morphological properties. LWT - Food Science and Technology, 49(1), 162169. https://doi.org/10.1016/j.lwt.2012.04.028

Gani, A., Gazanfar, T., Jan, R., Wani, S.M. and Masoodi, F.A. (2013). Effect of gamma irradiation on the physicochemical and morphological properties of starch extracted from lotus stem harvested from Dal lake of Jammu and Kashmir, India. Journal of the Saudi Society of Agricultural Sciences, 12(2), 109115. https://doi.org/10.1016/j.jssas.2012.08.004

Ghaffar, S., Abdulamir, A.S., Bakar, F.A., Karim, R. and Saari, N. (2009). Microbial growth, sensory characteristic and $\mathrm{pH}$ as potential spoilage indicators of Chinese yellow wet noodles from commercial processing plants. American Journal of Applied Sciences, 6(6), 1059-1066. https://doi.org/10.3844/ 
ajassp.2009.1059.1066

Guo, G., Jackson, D.S., Graybosch, R.A. and Parkhurst, A.M. (2003). Asian salted noodle quality: Impact of amylose content adjustments using waxy wheat flour. Cereal Chemistry Journal, 80(4), 437-445. https://doi.org/10.1094/CCHEM.2003.80.4.437

Ho, L.-H. and Che Dahri, N. (2016). Effect of watermelon rind powder on physicochemical, textural, and sensory properties of wet yellow noodles. CyTA - Journal of Food, 14(3), 465-472. https://doi.org/10.1080/19476337.2015.1134672

Hormdok, R. and Noomhorm, A. (2007). Hydrothermal treatments of rice starch for improvement of rice noodle quality. LWT - Food Science and Technology, 40(10), 1723-1731. https://doi.org/10.1016/ j.lwt.2006.12.017

Ismail, M.H., Law, C.L. and Hii, C.L. (2016). Transparency phenomena of flat-rice noodles (kuew teow) at drying at soaking variation. International Food Research Journal, 23(Suppl.), S195-S202.

Jeong, S., Kim, Y., Ko, S., Yoon, M-R., Lee, J-S. and Lee, S. (2016). Physicochemical characterization and in-vitro digestibility of extruded rice noodles with different amylose contents based on rheological approaches. Journal of Cereal Science, 71, 258-263. https://doi.org/10.1016/j.jcs.2016.09.004

Jianming, C. (1998). Preservation of fresh noodles by irradiation. Radiation Physics and Chemistry, 52(16), 35-38. https://doi.org/10.1016/S0969-806X(98) 00069-3

Kasemsuwan, T., Bailey, T. and Jane, J. (1998). Preparation of clear noodles with mixtures of tapioca and high-amylose starches. Carbohydrate Polymers, 36(4), 301-312. https://doi.org/10.1016/S0144-8617 (97)00256-7

Klinmalai, P., Hagiwara, T., Sakiyama, T. and Ratanasumawong, S. (2017). Chitosan effects on physical properties, texture, and microstructure of flat rice noodles. $L W T$ - Food Science and Technology, 76(PartA), 117-123. https:// doi.org/10.1016/j.lwt.2016.10.052

Köksel, H., Çelik, S. and Tuncer, T. (1996). Effects of gamma irradiation on durum wheats and spaghetti quality. Cereal Chemistry, 73(4), 506-509.

Lacroix, M., Ouattara, B., Saucier, L., Giroux, M. and Smoragiewicz, W. (2004). Effect of gamma irradiation in presence of ascorbic acid on microbial composition and TBARS concentration of ground beef coated with an edible active coating. Radiation Physics and Chemistry, 71(1-2), 73-77. https:// doi.org/10.1016/j.radphyschem.2004.04.057

Li, M., Zhu, K., Guo, X., Peng, W. and Zhou, H. (2011).
Effect of water activity (aw) and irradiation on the shelf-life of fresh noodles. Innovative Food Science and Emerging Technologies, 12(4), 526-530. https:// doi.org/10.1016/j.ifset.2011.06.005

Li, M., Zhu, K.X., Sun, Q.J., Amza, T., Guo, X.N. and Zhou, H.M. (2016). Quality characteristics, structural changes, and storage stability of semidried noodles induced by moderate dehydration: Understanding the quality changes in semi-dried noodles. Food Chemistry, 194, 797-804. https:// doi.org/10.1016/j.foodchem.2015.08.079

Li, Y., Liang, J.F., Yang, M.Y., Chen, J.Y. and Han, B.Z. (2015). Traditional Chinese rice noodles: History, classification, and processing methods. Cereal Foods World, 60(3), 123-127. https:// doi.org/10.1094/CFW-60-3-0515

Lu, Z.H. and Collado, L.S. (2010). Rice and StarchBased Noodles. In Hou, G.G. (Ed.) Asian Noodles: Science, Technology and Processing, p. 393-431. United Kingdom: John Wiley and Sons, Inc. https:// doi.org/10.1002/9780470634370.ch16

Lu, Z.-H. and Collado, L.S. (2019). 17 - Rice noodles. In Bao, J. (Ed.) Rice. $4^{\text {th }}$ ed. USA: AACC International. https://doi.org/10.1016/B978-0-12-811508-4.000174

Maherani, B., Hossain, F., Criado, P., Ben-Fadhel, Y., Salmieri, S. and Lacroix, M. (2016). World Market Development and Consumer Acceptance of Irradiation Technology. Foods, 5(4), 79. https:// doi.org/10.3390/foods5040079

Malahayati, N., Muhammad, K., Bakar, J. and Karim, R. (2015). Quality and fortificant retention of rice noodles as affected by flour particle size. Cereal Chemistry, 92(2), 211-217. https://doi.org/10.1094/ CCHEM-01-14-0011-R

Mason, W.R. (2009). Chapter 20 - Starch Use in Foods. In BeMiller, J. and Whistler, R. (Eds.). Starch. $3^{\text {rd }}$ ed., p. 745-795. USA: Elsevier, Inc. https:// doi.org/10.1016/B978-0-12-746275-2.00020-3

Mir, S.A., Bosco, S.J.D., Shah, M.A., Mir, M.M. and Sunooj, K.V. (2015). Effect of gamma irradiation on physicochemical properties of brown rice. International Journal of Food Engineering, 11(4), 563-571. https://doi.org/10.1515/ijfe-2015-0038

Nayak C.A., Chethana, S., Rastogi, N.K. and Raghavarao K.S.M.S. (2006). Enhanced mass transfer during solid-liquid extraction of gammairradiated red beetroot. Radiation Physics and Chemistry, 75(1), 173-178. https://doi.org/10.1016/ j.radphyschem.2005.03.015

Nielsen, S.S. (2017). Food Analysis. $5^{\text {th }}$ ed. USA: Springer. 
Noomhorm, A., Pungsawat, K., Sirisoontaralak, P. and Vongsawasdi P. (2005). Use of irradiation to Improve the safety and guality of chilled Pad Thai (Stir fry rice noodle with dried shrimp). International Symposium "New Frontier of Irradiated food and Non-food Product", KMUTT, Bangkok, Thailand, 2005. Bangkok, Thailand: KMUTT.

Odueke, O.B., Chadd, S.A., Baines, R.N., Farag, K.W. and Jansson, J. (2018). Effects of gamma irradiation on the shelf-life of a dairy-like product. Radiation Physics and Chemistry, 143, 63-71. https:// doi.org/10.1016/j.radphyschem.2017.09.013

Qazi, I.M., Rakshit, S.K., Tran, T., Javidullah and Khan, M.Z. (2014). Effect of blending selected tropical starches with rice flour on the cooking quality and texture of rice based noodles. Sarhad Journal of Agriculture, 30(2), 257-264.

Qing, T.Y. (2016). Shelf life study of homemade noodles incorporated with bell pepper (Capsicum sp.). Malaysia: Universiti Tunku Abdul Rahman, BSc. Thesis

Romano, A., Mackie, A., Farina, F., Aponte, M., Sarghini, F. and Masi, P. (2016). Characterisation, in vitro digestibility and expected glycemic index of commercial starches as uncooked ingredients. Journal of Food Science and Technology, 53(12), 4126-4134. https://doi.org/10.1007/s13197-0162375-9

Sandhu, K.S., Kaur, M. and Mukesh. (2010). Studies on noodle quality of potato and rice starches and their blends in relation to their physicochemical, pasting and gel textural properties. LWT - Food Science and Technology, 43(8), 1289-1293. https:// doi.org/10.1016/j.lwt.2010.03.003

Sangpring, Y., Fukuoka, M. and Ratanasumawong, S. (2015). The effect of sodium chloride on microstructure, water migration, and texture of rice noodle. LWT - Food Science and Technology, 64(2), 1107-1113. j.lwt.2015.07.035

Sirichokworrakit, S., Phetkhut, J. and Khommoon, A. (2015). Effect of partial substitution of wheat flour with riceberry flour on quality of noodles. Procedia Social and Behavioral Sciences, 197, 1006-1012. https://doi.org/10.1016/j.sbspro.2015.07.294

Sirisoontaralak, P. and Noomhorm, A. (2006). Changes to physicochemical properties and aroma of irradiated rice. Journal of Stored Products Research, 42(3), 264-276. https://doi.org/10.1016/ j.jspr.2005.04.001

Sung, W.C. (2005). Effect of gamma irradiation on rice and its food products. Radiation Physics and
Chemistry, 73(4), 224-228. https://doi.org/10.1016/ j.radphyschem.2004.08.008

Talja. R. A., Peura. M., Serimaa, R. and Jouppila, K. (2008). Effect of amylose content on physical and mechanial properties of potato-starch-based edible films. Biomacromolecules, 9(2), 658-663.

Teixeira, B.S., Inamura, P.Y. and Mastro, N.L.D. (2015). The influence of gamma irradiation on texture, color and viscosity properties of potato starch, presented at International Nuclear Atlantic Conference - INAC, São Paulo, SP, Brazil, 2015. São Paulo, SP, Brazil: International Nuclear Atlantic Conference

Thomas, R., Yeoh, T.K., Wan-Nadiah, W.A. and Bhat, R. (2014). Quality evaluation of flat rice noodles (kway teow) prepared from Bario and Basmati rice. Sains Malaysiana, 43(3), 339-347.

Wan Zunairah, W.I., Nuruladilah, M.P., Zainuri, A., Nor -Khaizura, M-A-R., Nor-Afizah, M., Ismail-Fitry, M.R., Radiah, S. and Nur-Hanani, Z.A. (2019). Effect of gamma irradiation on physicochemical properties and microbiological quality of wet yellow noodle fortified with water spinach (Ipomoea aquatica). Food Research, 4(1), 34-41. https:// doi.org/10.26656/fr.2017.4(1).140

Wang, J. and Chao, Y. (2003). Effect of ${ }^{60}$ Co irradiation on drying characteristics of apple. Journal of Food Engineering, 56(4), 347-351. https:// doi.org/10.1016/S0260-8774(02)00160-7

Wang, L., Zhang, C., Chen, Z., Wang, X., Wang, K., Li, Y., Wang, R., Luo, X., Li, Y. and Li, J. (2018). Effect of annealing on the physico-chemical properties of rice starch and the quality of rice noodles. Journal of Cereal Science, 84, 125-131. https://doi.org/10.1016/j.jcs.2018.10.004

Widjajaseputra, A.I. (2012). Relation of moisture distribution and texture of rice-based foods - a perspective. International Food Research Journal, 19(3), 1275-1278.

Yadav, A. and Singh, B. (2013). Effects of gamma irradiation on germination and physiological aspects of maize genotypes. International Journal of Biotechnology and Bioengineering Research, 4(6), 519-520.

Zawawi, N., Gangadharan, P., Ahma Zaini, R., Samsudin, M.G., Karim, R. and Maznah, I. (2014). Nutritional values and cooking quality of defatted Kenaf seeds yellow (DKSY) noodles. International Food Research Journal, 21(2), 603-608. 